\title{
Upaya Promotif untuk Meningkatkan Pengetahuan Ibu Bayi dan Balita tentang Stunting dengan Media Integrating Card
}

\author{
Sri Astuti ${ }^{1^{*}}$, Ginna Megawati ${ }^{1}$, Samson CMS ${ }^{2}$ \\ ${ }^{1}$ Departemen Ilmu Kesehatan Masyarakat, Fakultas Kedokteran, Universitas Padjadjaran \\ ${ }^{2}$ Program Studi Ilmu Perpustakaan, Fakultas IImu Komunikasi, Universitas Padjadjaran, Jatinangor, Sumedang, \\ Jawa Barat, Indonesia
}

Submisi: 04 Januari 2019 ; Revisi: 27 April 2020; Penerimaan: 05 Mei 2020

\begin{abstract}
Kata Kunci:
Abstrak Stunting adalah kondisi ketika seorang anak tingginya kurang dari

Balita

Bayi

Gizi

Kartu edukasi

Promosi

kesehatan tinggi standar usianya dan merupakan masalah kurang gizi kronis yang disebabkan oleh asupan gizi yang kurang dalam waktu yang cukup lama. Stunting dapat menyebabkan produktivitas seseorang terganggu saat dewasa. Hal ini terjadi karena stunting berdampak pada terganggunya pertumbuhan fisik, kekebalan tubuh, dan fungsi kognitif anak. Selain faktor gizi, stunting disebabkan oleh kurangnya pengetahuan masyarakat tentang stunting, terutama ibu hamil, ibu balita (bawah lima tahun), dan kader posyandu. Tujuan pemberdayaan masyarakat ini adalah meningkatkan pengetahuan ibu bayi dan balita melalui promosi kesehatan dengan media Integrating card. Dalam pemberdayaan masyarakat ini dilakukan juga penelitian dengan pendekatan cross-sectional. Subyek pada penelitian tersebut adalah 77 ibu yang memiliki bayi dan balita di wilayah kerja Puskesmas Jatinangor, Kabupaten Sumedang. Kegiatan promosi kesehatan dilaksanakan pada November 2018. Setelah dilakukan promosi kesehatan dengan Integrating card, 56 (72,7\%) peserta mempunyai tingkat pengetahuan yang baik dan cukup. Tingkat pengetahuan peserta meningkat seiring dengan pertambahan usia, tingginya pendidikan, pertambahan jumlah paritas, dan banyaknya kunjungan antenatal care (ANC). Ibu yang bekerja mempunyai tingkat pengetahuan yang lebih baik dibandingkan dengan ibu yang tidak bekerja. Integrating card dapat menjadi alternatif media yang menarik dan mudah digunakan dalam upaya mencegah dan menurunkan kejadian stunting.
\end{abstract}

Keywords:

Baby

Educational card

Health promotion

Nutrition

Under-five children
Abstract Stunting is a condition when a child's height less than the standard height of his age and is a chronic malnutrition problem caused by a lack of nutrition in a long time. Stunting can cause someone's productivity to be disturbed as an adult. This happens because stunting affects the disruption of physical growth, immunity, and cognitive function. In addition to nutritional factors, stunting is caused by a lack of knowledge of the community, especially pregnant women and mothers of under-five children and health cadre. Community empowerment aims to increase the knowledge of mothers of underfive children, through health promotion with Integrating card media. The method applied in this community empowerment is cross-sectional. The subjects in this study were 77 mothers of infants and under-five children in the work area of Jatinangor, Sumedang District, held in November 2018. After the health promotion with Integrating card executed, 56 participants $(72,7 \%)$ showed great and sufficient knowledge level. The level of knowledge of the participants increases with age, higher education, increases in the number of parity, and the number of antenatal care (ANC) visits. Working mothers have a better level of knowledge than mothers who do not work. Integrating cards can

${ }^{1}$ Departemen IImu Kesehatan Masyarakat, Fakultas Kedokteran, Universitas Padjadjaran, J. Raya Bandung Sumedang KM.21, Hegarmanah, Kec Jatinangor, Kab. Sumedang, Jawa Barat 45363

Email: sriastuti29a@gmail.com 
be an attractive and easy to use alternative media in an effort to prevent and reduce the incidence of stunting.

\section{PENDAHULUAN}

Anak dengan usia di bawah lima tahun (balita) pendek adalah balita yang berdasarkan panjang atau tinggi badan dan umurnya memiliki nilai z-score kurang dari -2SD dibandingkan dengan standar baku WHO-MGRS (Multicentre Growth Reference Study) tahun 2005, dan dikategorikan sangat pendek jika memiliki nilai z-score kurang dari -3SD (Kemenkes, 2016). Data Riset Kesehatan Dasar 2013 tentang status gizi balita pendek dan sangat pendek di Indonesia tahun 2013 menunjukkan angka 37,2\%. Jika dibandingkan dengan data $2010(35,6 \%)$ dan 2007 (36,8\%), angka tersebut tidak menunjukkan penurunan, justru kenaikan (Kemenkes, 2013). Persentase balita pendek di Jawa Barat sebesar 29,2\% (Dinas Kesehatan Kabupaten Sumedang, 2017), sedangkan di Kabupaten Sumedang jauh lebih besar (41,08\%).

Stunting merupakan masalah kurang gizi kronis yang disebabkan oleh asupan gizi yang kurang dalam waktu yang cukup lama. Asupan gizi yang dibutuhkan untuk mencegah stunting berupa asupan gizi yang baik saat hamil, konsumsi tablet penambah darah yang cukup saat hamil, pemberian ASI kepada anak selama enam bulan pertama, dan dilanjutkan dengan makanan pendamping ASI yang tepat sampai anak berusia dua tahun. Faktor-faktor lain yang berpengaruh terhadap kejadian stunting adalah kemampuan tenaga kesehatan dalam mendeteksi kondisi stunting sejak dini, kebersihan air dan lingkungan, pola pengasuhan anak, tempat persalinan, dan genetik. Anak-anak pendek menghadapi risiko yang lebih besar untuk tumbuh menjadi orang dewasa yang kurang berpendidikan, miskin, kurang sehat, dan lebih rentan terhadap penyakit tidak menular. Anak pendek merupakan prediktor buruknya kualitas sumber daya manusia, yang selanjutnya menurunkan produktivitas suatu bangsa di masa yang akan datang (UNICEF Indonesia, 2012).

Stunting dipengaruhi oleh berbagai kondisi lain yang secara tidak langsung memengaruhi kesehatan. Hasil penelitian Nadiyah et al. (2014) menunjukkan bahwa pendidikan ibu dan ayah berhubungan dengan stunting pada anak. Ibu dengan pendidikan rendah (tidak sekolah atau SD) berpeluang memiliki anak stunting 1,8 kali lebih besar dan ayah dengan pendidikan rendah berpeluang memiliki anak stunting 1,4 kali lebih besar. Selain itu, terdapat hubungan yang signifikan antara pendapatan keluarga dengan stunting pada anak. Berdasarkan penelitian Nadiyah et al. (2014) diketahui bahwa status ekonomi lebih banyak berpengaruh terhadap pertumbuhan linear daripada pertumbuhan berat badan sehingga terdapat hubungan antara status ekonomi dan stunting. Kurangnya keterlibatan petugas kesehatan dalam memberikan promosi nutrisi kepada para ibu selama kehamilan berdampak terhadap pengetahuan ibu serta kesehatan ibu dan anak (Jamila at al., 2017).

Stunting pada anak mencerminkan kondisi gagal tumbuh pada masa balita akibat kekurangan gizi kronis sehingga anak menjadi terlalu pendek untuk usianya. Kekurangan gizi kronis terjadi sejak bayi dalam kandungan hingga usia dua tahun. Dengan demikian periode 1000 hari pertama kehidupan seyogyanya mendapat perhatian khusus karena menjadi penentu tingkat pertumbuhan fisik, kecerdasan, dan produktivitas seseorang di masa depan. Di Indonesia, sekitar 37,2\% (hampir 9 juta) anak balita mengalami stunting (Riset Kesehatan Dasar, 2013). Indonesia adalah negara dengan prevalensi stunting kelima terbesar di dunia. Intervensi untk mencegah stunting telah dilakukan oleh pemerintah melalui Gerakan Scaling-Up Nutrition (SUN) yang diluncurkan dengan prinsip dasar bahwa semua penduduk berhak untuk memperoleh akses ke makanan yang cukup dan bergizi. Pada 2012, Pemerintah Indonesia bergabung dalam gerakan tersebut melalui perancangan dua kerangka besar intervensi stunting yaitu intervensi gizi spesifik dan intervensi gizi sensitif. Sejalan dengan program penurunan angka kejadian stunting, puskesmas dan posyandu melaksanakan program terkait intervensi gizi spesifik dan sensitif baik pada ibu hamil, ibu menyusui dengan bayi 0-6 bulan dan ibu dengan anak usia 0-23 bulan termasuk memberikan edukasi kesehatan.

Persentase stunting di wilayah kerja Puskesmas Jatinangor sebesar 19,23\%. Di Desa Cipacing, Kecamatan Jatinangor, Kabupaten Sumedang, tindakan yang dilakukan pada ibu balita dengan stunting adalah memberikan konseling tentang pemberian makanan, rangsangan motorik, dan bekerja sama dengan petugas gizi di puskesmas. Berdasarkan permasalahan tersebut, kegiatan pengabdian kepada masyarakat in dilaksanakan untuk meningkatkan pengetahuan ibu bayi dan balita tentang pencegahan stunting melalui promosi kesehatan dengan media Integrating card (singkatan dari INTEractive Game to eRAdicate stunTING). Integrating card bermakna kartu game interaktif untuk memerangi stunting. Tindakan preventif untuk memerangi stunting harus mengintegrasikan kategori pengetahuan stunting yang terdiri atas penyebab, dampak, dan pencegahannya. Pengetahuan ibu bayi dan balita di Kecamatan 
Jatinangor tentang pencegahan balita pendek masih kurang. Salah satu penyebabnya adalah kader posyandu belum pernah memberikan penyuluhan tentang pencegahan stunting karena tidak mengetahui informasi perihal stunting. Oleh karena itu, pemberian informasi tentang pencegahan stunting sangat.penting agar kejadian stunting dapat diturunkan. Sejalan dengan pendapat Maywita (2018), kegiatan promosi kesehatan dapat meningkatkan pengetahuan ibu balita dalam pencegahan stunting.

\section{METODE}

Kegiatan pemberdayaan masyarakat dilaksanakan bersamaan dengan penelitian dengan pendekatan cross-sectional yang bertujuan untuk mendapatkan gambaran pengetahuan ibu bayi dan balita mengenai stunting setelah dilakukan promosi kesehatan dengan media kartu. Subjek penelitian tersebut adalah 77 ibu bayi dan balita di wilayah kerja Puskesmas Jatinangor. Integrating card adalah media promosi interaktif berupa kartu yang berisi pengetahuan tentang stunting untuk mengedukasi para ibu bayi dan balita dengan bermain kartu secara mudah dan praktis. Gauthier et al. (2019) mengemukakan beberapa penelitian dalam upaya meningkatkan pengetahuan dan perilaku kesehatan masyarakat, salah satu di antaranya menggunakan permainan sebagai media. Permainan dengan kartu interaktif memiliki keunggulan, yaitu dapat lebih memfasilitasi interaksi tatap muka dengan teman sebaya, anggota keluarga, kader, bahkan dengan tenaga kesehatan daripada permainan digital. Selain itu, dikemukakan juga bahwa intervensi dengan media kartu untuk pendidikan kesehatan dapat meningkatkan pengetahuan dan perilaku yang berhubungan dengan kesehatan sebesar 76\% (Gauthier et al., 2019). Oleh karena itu, dalam kegiatan ini dilakukan inovasi edukasi dengan menggunakan kartu interaktif pencegahan stunting yang diberikan kepada para ibu bayi dan balita.

Media kartu berfungsi sebagai permainan dan edukasi. Setiap kartu diberi nomor dan terdiri atas kartu A, kartu B, dan joker yang berisi gambar dan pernyataan mengenai stunting yang terdiri dari tiga kategori (Gambar 1). Kategori penyebab diberi warna kuning, kategori dampak diberi warna merah, sedangkan kategori pencegahan diberi warna hijau). Gambar-gambar dalam kartu dibuat menarik dan relevan dengan informasi yang diberikan (Gambar 2).

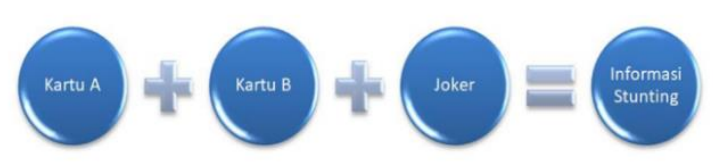

Gambar 1. Komponen INTEGRATING card

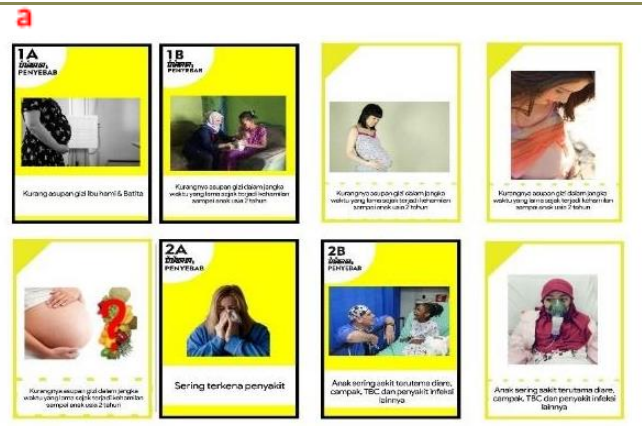

b
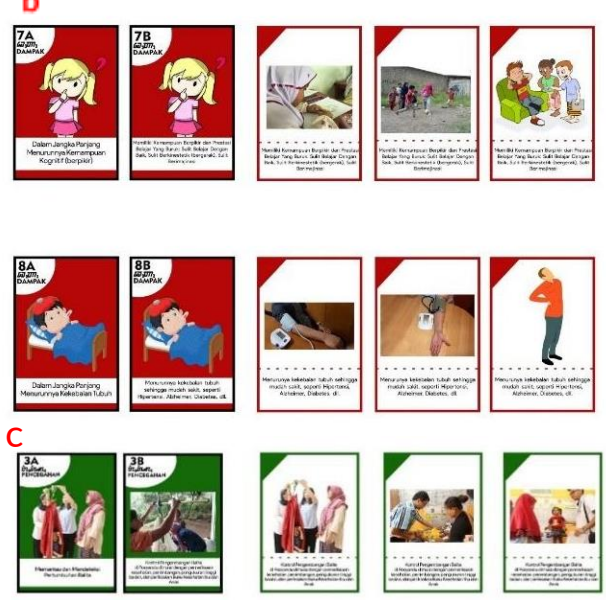

C
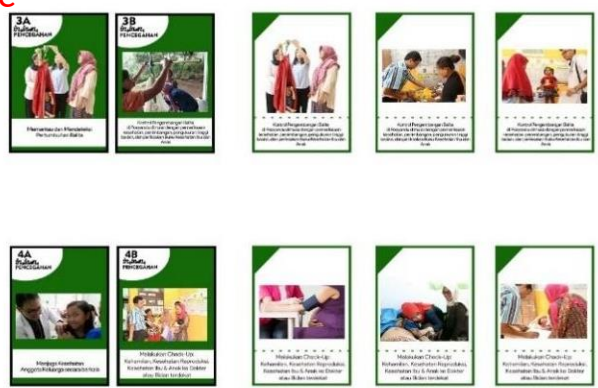

Gambar 2. Gambar-gambar dalam kartu. aKartu berwarna kuning berisi pernyataan penyebab stunting, kartu berwarna merah berisi pernyataan terkait dampak, danan kartu berwarna hijau berisi pernyataan tentang pencegahan stunting

Peserta dibagi ke dalam kelompok-kelompok kecil (Gambar 3). Permainan dimulai dengan sosialisasi penggunaan kartu oleh fasilitator (bidan desa atau kader posyandu) yang sudah dilatih untuk menggunkan kartu. Setiap peserta dipersilakan untuk mengambil satu kartu kemudian membaca isi kartu tersebut, sedangkan peserta yang lain diminta untuk menyebutkan apakah pernyataan tersebut termasuk kategori pencegahan, dampak, atau penyebab stunting. Kartu joker harus dicari pasangannya yang sesuai, baik pada kartu berwarna hijau, kuning, maupun merah. Masing-masing kategori dibuat menjadi beberapa kartu sesuai dengan materi yang akan disampaikan. Fasilitator melakukan tanya jawab dengan peserta untuk mengevaluasi pemahaman perihal stunting secara kualitatif. Selain itu, dilakukan juga tanya jawab dengan menggunakan kuesioner untuk mengukur tingkat pengetahuan peserta. Edukasi dengan media kartu dapat dilakukan pada beberapa kelompok sekaligus dengan memperbanyak set kartu terlebih dahulu. 
Tabel 1. Gambaran pengetahuan ibu bayi dan balita di wilayah kerja Puskesmas Jatinangor tentang stunting berdasarkan umur, tingkat pendidikan, pekerjaan, paritas, dan frekuensi antenatal care(ANC)

\begin{tabular}{|c|c|c|c|c|c|c|c|c|}
\hline \multirow{3}{*}{ Karakteristik } & \multicolumn{6}{|c|}{ Pengetahuan } & \multicolumn{2}{|c|}{ Total } \\
\hline & \multicolumn{2}{|c|}{ Baik } & \multicolumn{2}{|c|}{ Cukup } & \multicolumn{2}{|c|}{ Kurang } & \multirow[b]{2}{*}{$\mathbf{n}$} & \multirow[b]{2}{*}{$\%$} \\
\hline & $\mathrm{n}$ & $\%$ & $\mathrm{n}$ & $\%$ & $\mathrm{n}$ & $\%$ & & \\
\hline \multicolumn{9}{|l|}{ Umur } \\
\hline$<20$ & 0 & 0 & 1 & 50,0 & 1 & 50,0 & 2 & 100 \\
\hline $20-35$ & 16 & 29,6 & 22 & 40,7 & 16 & 29,6 & 54 & 100 \\
\hline$>35$ & 3 & 14,3 & 14 & 66,7 & 4 & 19,0 & 21 & 100 \\
\hline \multicolumn{9}{|l|}{ Pendidikan } \\
\hline $\mathrm{SD}$ & 2 & 18,2 & 4 & 36,4 & 5 & 45,4 & 11 & 100 \\
\hline SMP & 6 & 16,2 & 21 & 56,8 & 10 & 27,0 & 37 & 100 \\
\hline SMA/SMK & 9 & 36,0 & 10 & 40,0 & 6 & 24,0 & 25 & 100 \\
\hline Perguruan Tinggi & 2 & 50,0 & 2 & 50,0 & 0 & 0 & 4 & 100 \\
\hline \multicolumn{9}{|l|}{ Pekerjaan } \\
\hline Bekerja & 2 & 25,0 & 5 & 62,5 & 1 & 12,5 & 8 & 100 \\
\hline Tidak Bekerja & 17 & 24,6 & 32 & 46,4 & 20 & 29,0 & 69 & 100 \\
\hline \multicolumn{9}{|l|}{ Paritas } \\
\hline Primipara & 8 & 38,1 & 6 & 28,6 & 7 & 33,3 & 21 & 100 \\
\hline Multipara & 11 & 19,7 & 31 & 55,3 & 14 & 25 & 56 & 100 \\
\hline \multicolumn{9}{|l|}{ Pemeriksaan ANC } \\
\hline$<4 \mathrm{x}$ & 0 & 0 & 2 & 66,7 & 1 & 33,3 & 3 & 100 \\
\hline$>4 x$ & 19 & 25,7 & 35 & 47,3 & 20 & 27,0 & 74 & 100 \\
\hline
\end{tabular}

Kegiatan promosi kesehatan ini dilaksanakan pada November 2018 di Desa Cilayung, Desa Cikeruh, dan Desa Cipacing, yang merupakan wilayah kerja Puskesmas Jatinangor, Kecamatan Jatinangor, Kabupaten Sumedang. Penelitian sudah mendapatkan izin etik penelitian dari Fakultas Kedokteran Universitas Padjadjaran dengan No. 449/UN6.KEP/EC/2018.

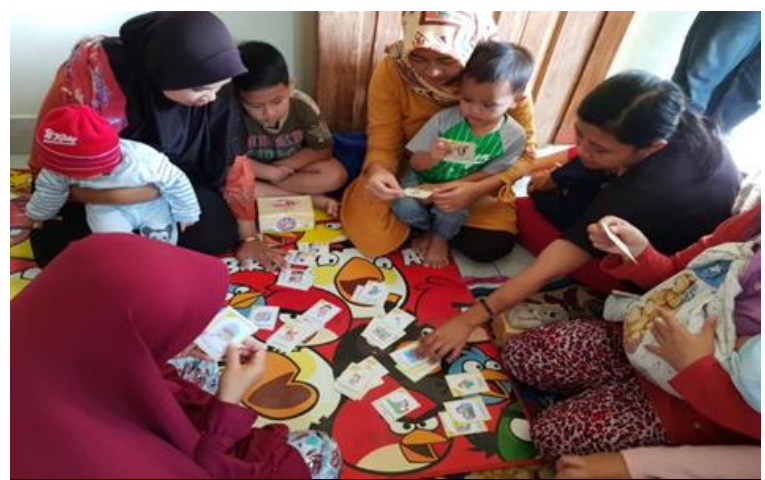

Gambar 3. Promosi kesehatan menggunakan media kartu pencegahan stunting

\section{HASIL DAN PEMBAHASAN}

Setelah dilakukan promosi kesehatan dengan Integrating card, $56(72,7 \%)$ peserta mempunyai tingkat pengetahuan yang baik dan cukup. Tingkat pengetahuan peserta meningkat seiring dengan pertambahan usia, tingginya pendidikan, pertambahan jumlah paritas, dan banyaknya kunjungan antenatal care (ANC). Ibu yang bekerja mempunyai tingkat pengetahuan yang lebih baik dibandingkan dengan ibu yang tidak bekerja (Tabel 1).
Tingkat pengetahuan seorang ibu merupakan salah satu faktor yang berkaitan dengan kejadian stunting (Amir, 2018). Seorang ibu yang memiliki Frekuensi ANC berhubungan dengan pengetahuan dan kejadian stunting. Menurut Aguayo (2014), kejadian stunting lebih tinggi terjadi pada ibu yang melakukan ANC $\leq 3$ kali. Pemeriksaan kehamilan dapat mendeteksi secara dini risiko terjadinya komplikasi pada kehamilan dan persalinan, serta memantau kesehatan ibu dan janin (Kemenkes, 2013). Bidan dan dokter juga dapat memberikan informasi yang diperlukan saat kunjungan ibu. Setiap ibu yang memeriksakan kehamilannya, baik ke bidan, dokter, maupun ke posyandu akan mendapat informasi tentang kesehatan.

Salah satu upaya untuk meningkatkan pemahaman dan pengetahuan ibu mengenai faktor risiko dan pencegahan stunting adalah melakukan penyuluhan (promosi kesehatan) menggunakan media interaktif. Pada penelitian ini, $80 \%$ ibu bayi dan balita menyatakan bahwa Integrating card efektif digunakan untuk meningkatkan pengetahuan karena menarik dan lebih mudah dipahami.

Surat keputusan Menteri Kesehatan republik Indonesia menyebutkan bahwa promosi kesehatan adalah upaya untuk meningkatkan kemampuan masyarakat melalui pembelajaran dari, oleh, untuk, dan bersama masyarakat yang dapat mengembangkan kegiatan bersumber daya masyarakat sesuai kondisi sosial budaya setempat (Kemenkes, 2007). Maywita (2018) menyatakan bahwa promosi kesehatan adalah 
kegiatan atau usaha untuk menyampaikan informasi kesehatan kepada masyarakat sehingga dapat meningkatkan pengetahuan tentang kesehatan yang lebih baik. Pada penelitian ini, tingkat pengetahuan ibu dapat ditingkatkan melalui promosi kesehatan menggunakan Integrating card.

\section{KESIMPULAN}

Promosi kesehatan menggunakan media Integrating card dapat meningkatkan pengetahuan ibu bayi dan balita mengenai stunting. Media kartu merupakan media non-digital yang menarik dan relatif mudah digunakan oleh ibu bayi dan balita, kader posyandu, atau bidan desa. Integrating card dapat menjadi alternatif media promosi kesehatan untuk mencegah dan menurunkan kejadian stunting.

\section{Referensi}

Aguayo, V.M., Badgaiyan, N., \& Paintal, K. (2014). Determinants of Child Stunting in the Royal Kingdom of Bhutan: an in-Depth Analysis of Nationally Representative Data. United Nations Children's Fund (UNICEF), Regional Office for South Asia, Kathmandu, Nepal. In The Authors. Maternal and Child Nutrition. (2015, pp. 333-345). Published by John Wiley \& Sons Ltd, 11. doi:10.1111/mcn.12168

Amir, H. (2018). Pengaruh Peran Kader Kesehatan terhadap Peningkatan Status Gizi Bayi, Balita di Wilayah Kerja Puskesmas Sangkub. Paradigma, Vol. 6, pp. 17-27.

Erna, K., Rahardjo, S., \& Sari, H.P. (2015). Model Pengendalian Faktor Risiko Stunting pada Anak Usia di Bawah Tiga Tahun. Jurnal Kesehatan Masyarakat Nasional, 9(3), Februari 2015.

Gauthier, A., Pamela, M. K., Kim, C.M. Bul, Dunwell, I., Walker-Clarke, A., \& Lameras, P. (2019). Board Games for Health: A Systematic Literature Review and Meta-Analysis. Games for Health Journal: Research, Development, and Clinical Applications, 8(2), Mary Ann Liebert, Inc. doi:0.1089/g4h.2018.0017

Arrish, J., Yeatman, H., \& Wiiliamson, M. (2017). Midwives' Role in Providing Nutrition Advice during Pregnancy: Meeting the Challenges? A Qualitative Study. Australia. Dipublikasikan pada 2 Juli 2017.

Kemenkes. (2007). Kepmenkes No. 585/Menkes/SK/V/2007 tentang Pedoman Pelaksanaan Promosi Kesehatan di Puskesmas.

Kemenkes. (2013). Kerangka Kebijakan Gerakan Nasional Percepatan Perbaikan Gizi dalam Rangka Seribu Hari Pertama Kehidupan (Gerakan 1000 HPK). Jakarta: Informasi dan Pusat Data.

Kemenkes (2013). Hasil Riset Kesehatan Dasar 2013. Jakarta: Badan Penelitian dan Pengembangan Kesehatan
Kemenkes. (2013). Buku Saku Pelayanan Kesehatan Ibu di Fasilitas Kesehatan Dasar dan Rujukan: Pedoman bagi Tenaga Kesehatan. Edisi Pertama. Jakarta: WHO, Kemenkes, POGI, IBI.

Kemenkes. (2016). Situasi Balita Pendek. Jakarta: Informasi dan Pusat Data.

Maywita, E. (2018). Faktor Risiko Penyebab Terjadinya Stunting pada Anak Balita Umur 12-25 Bulan di Kelurahan Kampung Baru Kecamatan Begalang Tahun 2015. Jurnal Riset Hesti Medan, Vol. 3, pp. 56-65.

Nadiyah, Briawan, D., Martianto, D. (2014). Faktor Risiko Stunting pada Anak Usia 0-23 Bulan di Provinsi Bali, Jawa Barat, dan Nusa Tenggara Timur. Jurnal Gizi dan Pangan, 9(2): 125132.

Notoatmodjo. (2010). Ilmu Perilaku Kesehatan. Jakarta: PT Rineka Cipta.

Syabandini et al. (2018). Faktor Risiko Kejadian Stunting pada Anak Usia 6-24 Bulan di Daerah Nelayan. Jurnal Kesehatan Masyarakat, Vol. 6, pp. $496-507$. 